2. Наявність дисбалансу у сироватковому рівні про- та протизапальних цитокінів, поєднане із достовірно підвищеним рівнем патогенних ЦІК малого та середнього розміру, сприяє подальшому прогресуванню ураження нирок у хворих із поєднаною патологією.

\section{ЛІТЕРАТУРА:}

1. Воспалительные реакции у больных ишемической болезнью сердца с сопутствующими ожирением и сахарным диабетом 2 типа / И. И. Чукаева, Н. В. Орлова, В. А. Алешкин, А. Л. Пухальский, Е. Г. Алексеева, О. Н. Горина, Г. В. Шмарина, О. В.Захарова // Клиническая медицина. - 2008. - №1. - С. 27-30.

2. Діагностика і лікування метаболічного синдрому, цукрового діабету, предіабету і серцевосудинних захворювань: метод рекомендації / уклад. О.І. Мітченко, B.В.Корпачев; Національна академія медичних наук України, Державна установа «Національний науковий центр Інститут кардіології імені акад.. М. Д. Стражеска». - К. - 2009. - 40 с.

3. Залесский B. Н. Аутоиммунные и иммуновоспалительные процессы при атеросклерозе, его нутриентопрофилактика и терапия: Монография / Залесский В. Н., Гавриленко Т. И. - К.: «Віпол», 2008. - 592с.

4. Ильченко С. И. Диагностическая значимость уровня сывороточного трансформирующего фактора роста у детей с рецидивирующими и хроническими бронхитами / С. И. Ильченко // Журнал «Здоровье ребенка». - 2008. - № 6(15). - С. 28- 36.

5. Коваленко В. Н. Возможности корригирующего влияния системной энзимотерапии на компоненты син- дрома инсулинорезистентности / В. Н. Коваленко, Т. В. Талаева, В. В. Братусь // Рациональная фармакотерапия. - 2009. - №3. - С.70-77.

6. Передерий В. Г. Иммунный статус, принципы его оценки и коррекции иммунных нарушений / В. Г. Передерий, А. М. Земсков, Н. Г. Бычкова, В. М. Земсков. - К.: Здоров'я, 1995. - 211с.

7. Про затвердження клінічних протоколів надання медичної допомоги за спеціальністю «Пульмонологія»: Наказ МО3 України від 19.03.2007p. за №128.Київ - 2007. - 146 с.- Режим доступу: http:// medstandart.net/browse/2453

8. Про затвердження клінічних протоколів надання медичної допомоги за спеціальністю «Нефрологія»: Наказ МО3 України від 02.12.2004p. за №593. Режим доступу: http://medstandart.net/browse/1653

9. Расин М. С. Роль ядерных транскрипционных факторов в синтропии современной внутренней патологии / М. С. Расин, И. П. Кайдашев // Український медичний часопис. - 2014. - №1. - С.17-21.

10. Юбицкая Н. С. Роль фактора некроза опухоли в развитии метаболического синдрома / Н. С. Юбицкая, М. В. Антонюк, Л. В. Веремчук, К. К. Ходосова // Терапевтический архив. - 2009. - №11. - С. 59-63.

11. Brunzell $J$. Management in patients with cardiometabolic risk. Consensus statement from the American diabetes association and the American colledge of cardiology / J. Brunzell, M. Davidson, C. Furberg [et al.] // Diabetes Care. - 2008. - Vol. 31. - P. 811-822.

Надійшла до редакції 25.09.2014 Прийнята до друку 23.11.2014

(с) Лобода О.М., Красюк І.В., Алєксєєва В.В., Король Л.В., Дріянська В.Є., Дудар I.О., 2015

УДК 616.61-008.64-071:611.018.74

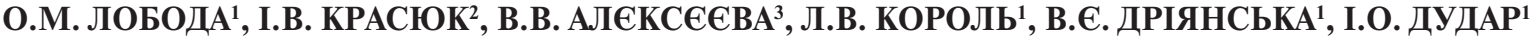

ВЗАЕМОЗВ'ЯЗОК ПРОЦЕСІВ ПЕРЕКИСНОГО ОКИСЛЕННЯ ЛІПІДІВ ТА ХРОНІЧНОГО ЗАПАЛЕННЯ З АТЕРОСКЛЕРОТИЧНИМИ ЗМІНАМИ СУДИН ТА ПОКАЗНИКАМИ ЕНДОТЕЛІАЛЬНОЇ ДИСФУНКЦІЇ У ХВОРИХ НА ХХН ІІ-ІV СТАДІЙ

\author{
O.M. LOBODA', I.V. KRASYUK ${ }^{2}$, V.V.ALEXEEVA ${ }^{3}$, L.V. KOROL ${ }^{1}$, V.Y. DRIYANSKA ${ }^{1}$ I.O. DUDAR
}

\title{
RELATIONSHIP OF LIPID PEROXIDATION PROCESSES AND CHRONIC INFLAMMATION WITH ATHEROSCLEROTIC VASCULAR CHANGES AND INDICATORS ENDOTHELIAL DYSFUNCTION IN PATIENTS WITH CKD STAGES II-IV
}

'Державна установа «Інститут нефрології Національної академії медичних наук України», Київ ${ }^{2}$ Національний медичний університет імені О. О. Богомольця, Київ

${ }^{3}$ Київська міська клінічна лікарня №3, Київ

${ }^{1}$ State Institution «Institute of Nephrology of National Academy Medical Sciences of Ukraine», Kyiv ${ }^{2}$ Bogomolets National Medical University, Kyiv

${ }^{3}$ Kyiv City Clinical Hospital №3, Kyiv

Лобода Олена Миколаївна doctor_yelena@ukr.net

Ключові слова: хронічна хвороба нирок, перекисне окиснення ліпідів, хронічне запалення, атеросклероз, ендотеліальна дисфункція.

Key words: chronic kidney disease, lipid peroxidation, chronic inflammation, atherosclerosis, endothelial dysfunction. 
Резюме. Целью нашей работы было определение взаимосвязей процессов атерогенеза и показателей эндотелиальной дисфункции с процессами активизации перекисного окисления липидов (ПОЛ) и хронического воспаления у больных ХБП II-IV стадий.

Материал и методы. У 90 больных ХБП II-IV стадии (30 - ХБП II стадии, 31 больных ХБП ІІІ стадии и 29 больных ХБП IV стадии) и 30 здоровых лии (группа контроля) определяли уровни провоспалительных и противовоспалительных иитокинов, показатели ПОЛ, толщину комплекса интима-медиа (КИМ) сонной артерии, лодыжечно-плечевой индекс (ЛПИ). Проведен корреляционный анализ для выявления возможной связи межжу полученными показателями атеросклеротического поражения сосудов и эндотелиальной дисфункции и показателями ПОЛ и про- и противовоспалительных цитокинов.

Результаты. Среднее содержание интерферон- $\gamma$, интерлейкин (ИЛ)- $1 \beta$ и ИЛ-10 у больных ХБП II-IV cm. было достоверно повышено по сравнению с соответствующими значениями в группе контроля. Среднее содержание малонового диальдегида (МДА) сыворотки и МДА эритроцитов у больных ХБП было достоверно повышено по сравнению с соответствующими значениями в группе контроля, а показатели антиоксидантной защиты - общая пероксидазная защита эритроцитов и содержание сульфгидрильных групп в сыворотке крови были достоверно снижены относительно соответствующих значений в группе контроля. Среди 90 больных ХБП II-IV cm. у 39 (43\%) регистрировались атеросклеротические изменения сонных артерий. Среди них утолщение КИМ (от 0,91 до 1,29 мм) определили у 22 (56\%) больных и наличие атеросклеротических бляшек (КИМ $\geq 1,3$ мм) у 17(44\%) больных. Двустороннее атеросклеротическое поражение сонных артерий наблюдалось у 14 (36\%) больных ХБП II-IV cm. Эндотелиальная дисфункция наблюдалась у 71 (79\%) больных ХБП II-IV ст. Обнаружена статистически значимая связь между показателями хронического воспаления, ПОЛ и показателями атеросклеротического поражения сосудов и эндотелиальной дисфункции.

Заключение. Патологические процессы активации ПОЛ, хронического воспаления тесно связаны между собой и прогрессированием атеросклеротического поражения сосудов при ХБП.

Summury. The aim of our study was to determine the relationship of processes of atherogenesis and indicators of endothelial dysfunction with the processes of activation of lipid peroxidation (LPO) and chronic inflammation in patients with CKD stages $I I-I V$.

Material and methods. Levels of proinflammatory and anti-inflammatory cytokines, indicators of lipid peroxidation, the thickness of the intima-media (IMT) of the carotid artery, ankle-brachial index (ABI) were measured in 90 patients with CKD stage II-IV (30 - CKD st. II, 31 patients with CKD st. III and 29 st. IV CKD patients) and 30 healthy subjects (control group). The correlation analysis was performed to identify the possible association between the obtained parameters of atherosclerotic vascular lesions and endothelial dysfunction and indices of lipid peroxidation and pro- and anti-inflammatory cytokines.

Results. The average levels of interferon- $\gamma$, interleukin (IL) - $1 \beta$ and IL-10 in patients with CKD II-IV Art. were significantly increased compared with the corresponding values in the control group. The average levels of malondialdehyde (MDA) of serum and MDA of erythrocyte in CKD patients was significantly increased compared with the corresponding values in the control group, and the antioxidant system indices - total peroxidase activity of erythrocytes and serum levels of the sulfhydryl groups was significantly reduced relative to the corresponding values in the group control. 39 (43\%) patients with CKD st. II-IV were recorded carotid atherosclerotic changes. The IMT (from 0.91 to $1.29 \mathrm{~mm}$ ) defined in 22 (56\%) patients and atherosclerotic plaques (IMT $\geq 1,3 \mathrm{~mm})$ defined in 17(44\%) patients. Bilateral carotid atherosclerotic lesions was observed in 14 (36\%) patients with CKD st. II-IV. Endothelial dysfunction was observed in 71 (79\%) patients with CKD st. II-IV. There was a statistically significant association between indicators of chronic inflammation, lipid peroxidation and indicators of atherosclerotic vascular lesions and endothelial dysfunction.

Conclusion. Pathological processes of LPO activation, chronic inflammation are closely linked between themselves and progression of atherosclerotic vascular lesions in $C K D$.

ВСТУП. Кількість хворих на хронічну хворобу нирок (ХХН) в Україні, як і в усьому світі, постійно збільшується [3]. Кардіоваскулярні захворювання залишається основною причиною смерті не тільки здорових людей, а і тим паче хворих на хронічну хворобу нирок [9]. Враховуючи те, що атеросклероз починається на ранньому етапі життя і може приховано прогресувати протягом десятиліть, з'явилась потреба виявляти індивідів без наявних симптомів, проте із високим ризиком, допоки не стався сам напад, який може мати фатальні наслідки. Вдалось виявити, що зміни у товщині комплексу інтима-медіа сонної артерії (ТКІМСА) пов'язані із змінами у кількості атеросклеротичних бляшок [6]. Окрім того, результати декількох паралельних спостережень виявили, що товщина шару інтимамедіа являє собою незалежний фактор ризику для появи латентних СС3, гострого інфаркту міокарда та інсульту [14, 16, 17]. Саме у зв’язку із цим, задля вимірювання ТКІМСА і було запропоновано використовувати В-режим ультразвукової діагностики, як неінвазійну, високочутливу методику, яка б визначила та кількісно відобразила ранні симптоми судинного захворювання, а також ризик появи CC3.

Процеси атерогенезу тісно пов'язані з процесами порушення ліпідного обміну, активацією процесів ПОЛ, toll-подібними рецепторами, які провокують нову хвилю запальної реакції, у якій беруть участь цитокіни, хемокіни, протеази, а та- 
кож вільні радикали. Попередні наші дослідження показали, що при ХХН відбувається активація процесів ПОЛ та хронічного запалення, крім того було показано, що прогресування ХХН позитивно корелює із цими процесами $[4,5]$.

Метою нашої роботи було визначення взаємозв'язків процесів атерогенезу та показників ендотеліальної дисфункції з процесами активізації ПОЛ та хронічного запалення у хворих на XXH IIIV стадіями.

МАТЕРІАЛ ТА МЕТОДИ. Спостереження, представлені в роботі, проведені у Київському міському науково-практичного центрі нефрології та гемодіалізу, що є клінічною базою ДУ «Інститут нефрології АМН України». Обстежено 90 осіб, що перебували на стаціонарному та/або амбулаторному лікуванні. При проведенні клініко-діагностичних та лікувальних заходів спиралися на протоколи діагностики та лікування, затверджені наказом МОЗ та НАМН України від 11.05.2011 р. № 280/44, на рекомендації KDOQI та KDIGO 3 діагностики та лікування ХXH.

Усі хворі дали інформовану згоду на участь у дослідженні.

Характеристика обстежених осіб за статтю та віком представлена у табл. 1.

Таблиця 1

Розподіл обстежених осіб за віком і статтю

\begin{tabular}{|l|c|c|}
\hline \multirow{2}{*}{\multicolumn{1}{|c|}{ Стать }} & \multicolumn{2}{|c|}{ Вікові групи } \\
\cline { 2 - 3 } & $\mathbf{4 5 - 5 9}$ років & $\mathbf{6 0 - 7 4}$ роки \\
\hline Чоловіки $(n=40)$ & $23(25 \%)$ & $16(18 \%)$ \\
\hline Жінки $(n=50)$ & $29(33 \%)$ & $22(24 \%)$ \\
\hline Всього $(n=90)$ & $52(58 \%)$ & $38(42 \%)$ \\
\hline
\end{tabular}

Примітка: дані представлені у вигляді n (\%)

За основу поділу за віком були прийняті якісні вікові періоди, рекомендовані ВОО3: середній (45 - 59 років) та похилий $(60-74$ роки). Осіб молодого $(16-29$ років), зрілого ( $30-44$ роки $)$, старечого (75 - 89 років) віку та довгожителів (90 років і старше) серед обстежених не було. Переважали особи середнього віку.

Стадію ХХН визначали згідно класифікації, прийнятої II національним з'їздом нефрологів України (2005) [2].

Характеристика даних хворих представлена у табл. 2.

Хворим визначали показники ПОЛ/АОС, показники хронічного запалення: про-та протизапальні цитокіни (ІН- $\gamma$, ІЛ-1 $\beta$ та ІЛ-10).
Усі суб'єкти підлягали ехокардіографічному (ЕхоКГ) дослідженню з визначенням комплексу інтим-медіа (КIM) сонної артерії на ультразвуковій системі «Aloka SSD 2000» (Японія) за допомогою датчика з частотою 7,5 МГц згідно з рекомендаціями Американського ЕхоКГ-товариства.

Наявність атеросклеротичного ураження підтверджується при потовщенні KIM (>0,9 мм), критерієм наявності атеросклеротичної бляшки (АТБ) $€$ значення КІМ рівний 1,3 мм. За АТБ приймається локальне чи пролонговане потовщення стінки артерії з боку іiї просвіту >1,3 мм або стенозу >20\% від діаметру артерії [1, 8]. При їх аналізі враховуються розмір, локалізація, форма, структура та ехогенність.

\section{Клініко-лабораторна характеристика хворих залежно від стадії XXН}

\begin{tabular}{|l|c|c|c|}
\hline \multirow{2}{*}{\multicolumn{1}{|c|}{ Показник }} & \multicolumn{3}{|c|}{ Група хворих } \\
\cline { 2 - 4 } & II ст. & III ст. & IV ст. \\
\hline Стать: чоловіки & 15 & 16 & 14 \\
жінки & 15 & 15 & $57 \pm 10,2$ \\
\hline Вік, роки & $58 \pm 8,7$ & $59 \pm 9,5$ & $135(130 ; 145)$ \\
\hline САТ, мм рт. ст. & $130(130 ; 145)$ & $130(130 ; 140)$ & $80(80 ; 95)$ \\
\hline ДАТ мм рт. ст. & $80(80 ; 90)$ & $80(80 ; 90)$ & $1,49 \pm 0,80$ \\
\hline Протеїнурія, г/добу & $1,44 \pm 0,81$ & $1,58 \pm 0,75$ & $96,4 \pm 5,1$ \\
\hline Гемоглобін, г/л & $112,6 \pm 7,4$ & $106,1 \pm 5,6$ & $24,5 \pm 4,4$ \\
\hline ШКФ, мл/хв $/ 1,73$ м $^{2}$ & $72,9 \pm 6,2$ & $41,1 \pm 6,5$ & \\
\hline
\end{tabular}

Примітка: дані представлені у вигляді M \pm SD при нормальному розподілі або як медіана (25 перцентиль: 75 перцентиль) при іншому. 
Для оцінки атеросклеротичного ураження артерій нижніх кінцівок застосовували вимірювання регіонального АТ в артеріях нижніх кінцівок 3 оцінкою гомілково-плечовий індекс (ГПІ), який розраховується як співвідношення АТ на гомілці та AT на плечі і визначається за допомогою ультразвукового дослідження. В загально прийнятій методиці використовується манжета сфігмоманометру, котра розміщується одразу над гомілками, та допплерівський датчик, який використовують для вимірювання систолічного АТ на задній великогомілковій артерії та артерії тилу стопи кожної ноги. Після цього цифри АТ співвідносяться з АТ на плечі кожної руки, що дозволяє розрахувати ГПІ. Кінцівка ГПІ зазвичай визначається як кінцівка 3 самим низьким ГПІ. У здорових людей ГПІ коливається в межах від 1,0 до 1,3. При зниженні цього показника менш ніж 0,9 слід вважати, що має місце гемодинамічно значуща патологія артерій нижніх кінцівок [12]. В останні роки в літературі з'явились данні, що ГПІ <0,9 є незалежним фактором ризику розвитку КВ3 (нестабільної стенокардії, не фатального інфаркту міокарда, «раптової» смерті). Початковий ступінь атеросклерозу ПА діагностується при ГПІ від 0,7 до 0,9; помірний - при ГПІ від 0,4 до 0,7 та високий - при ГПІ менш ніж 0,4. Чутливість цього методу для діагностики атеросклерозу плечової артерії згідно літературних даних становить $97 \%$, специфічність - 100\% [7].

Всім хворим також визначали функціональний стан ендотелію судин шляхом вимірювання ендотелій залежної вазодилятації (ЕЗВД) за методикою, яку описав D. Celermajer [13].

Дослідження виконані із дотриманням положень конвенції Ради Європи про права людини та біомедицину, Гельсинської декларації останнього перегляду та рекомендацій Комітету з біоетики при Президії НАМН України.

Для статистичного аналізу даних використовували пакет прикладних програм statistica (StatSoft, USA, v6.0). Застосовували методи непараметричної статистики - U-критерій Манна-Уітні для порівняння показників у двох групах, рангові кореляції Спірмена для встановлення наявності та сили зв'язку між досліджуваними показниками. Статистично значущими вважали відмінності при $\mathbf{p}<0,05$. При описуванні кількісних ознак було наведено середні значення та їх стандартні відхилення $(\mathrm{M} \pm \mathrm{SD})$. Отримані в результаті досліджень цифрові дані оброблялися на персональному комп'ютері за допомогою прикладних комп'ютерних програм: Microsoft Excel 2007, Statistica 7.0.

РЕЗУЛЬТАТИ ДОСЛІДЖЕННЯ ТА ЇХ ОБГОВОРЕННЯ. У 90 хворих на XXН II-IV стадії (30 - на XXН II стадії, 31 хворих на XXН III стадії та 29 хворих на XXH IV стадіï) та 30 здоровим особам (група контролю) визначали рівні прозапальних та протизапальних цитокінів.

Вміст ІН- $\gamma$ в сироватці крові у всіх досліджуваних (100\%) хворих був підвищеним. Коливання значень активності ІН- $\gamma$ було від 101,8 пг/мл до 187,2 пг/мл.

Рівні ІЛ-1 $\beta$ та ІЛ-10 у сироватці крові також були підвищеними у всіх досліджуваних (100\%) хворих. Коливання значень активності ІЛ-1 $\beta$ сироватці крові були від 110,4 пг/мл до 174 пг/мл та ІЛ-10 від 31 пг/мл до 116,9 пг/мл.

Середній вміст ІН- $\gamma$, ІЛ- $1 \beta$ та ІЛ-10 у хворих на XXH II-IV ст. був достовірно підвищений від відповідних значень в групі контролю - див. рис. 1.

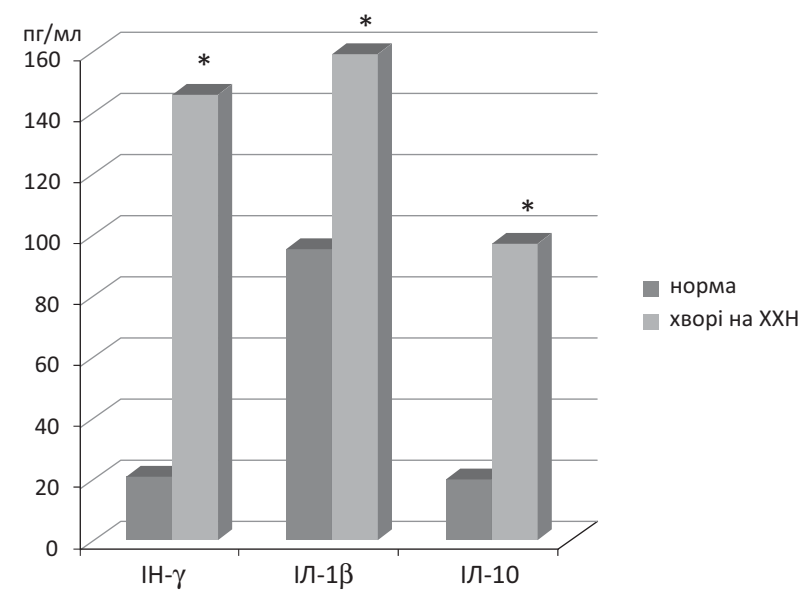

* - різниця з нормою достовірна $(\mathrm{p}<0,001)$

Рис. 1. Рівень цитокінів у крові хворих на XXН II-IV ст.

Достовірно підвищений рівень ІЛ- $1 \beta$ та IH- $\gamma$

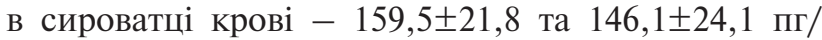
мл проти 94,9 $\pm 2,8$ та 20,2 $\pm 2,2$ пг/мл відповідно ( $<<0,001$ для обох цитокінів) свідчить про високу активність клітин моноцитарно-макрофагального ряду та Т-хелперів 1 типу у досліджуваних хворих. Такі рівні прозапальних цитокінів можуть не тільки ініціювати, але і підтримувати процес хронічного запалення та до того ж, можуть бути додатковим фактором розвитку апоптозу клітин $[10,11,15]$.

Оцінка показників перекісного окислення ліпідів та антиоксидантного захисту у хворих на хронічну хворобу нирок II-IV стадії показала, що вміст МДА в сироватці крові був підвищеним у 80 (89\%) хворих та у 10 (11\%) пацієнтів не відрізнялася від нормальних значень. Коливання показників активності МДА сироватки було від 64,3 мкмоль/л до 707,3 мкмоль/л.

Вміст МДА еритроцитів був підвищеним у 60 (67\%) хворих та у 30 (33\%) не відрізнялася від нормальних значень. Коливання показників активності МДА еритроцитів було від 450,1 мкмоль/л до 1414,6 мкмоль/л.

ЗПА еритроцитів була зниженою у 70 (78\%) та у 20 (22\%) не відрізнялася від нормальних значень. Коливання значень активності ЗПА було від 159,9 мкмоль/хв. на 1 г Нb до 489,7 мкмоль/хв. на 1 г Нb.

Вміст SH-груп у сироватці крові був зниженим у $80(89 \%)$ та у 10 (11\%) не відрізнявся від нормальних значень. Коливання значень рівнів $\mathrm{SH}$-груп в сироватці крові було від 1,1 ммоль/л до 2,34 ммоль/л. 
Середній вміст МДА сироватки та МДА еритроцитів у хворих на ХХН був достовірно підвищений в порівнянні з відповідними значеннями в групі контролю, а показники АОС - ЗПА еритро-

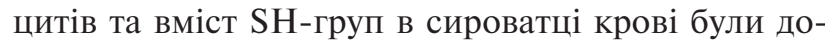
стовірно знижені від відповідних значень в групі контролю - див. рис. 2.

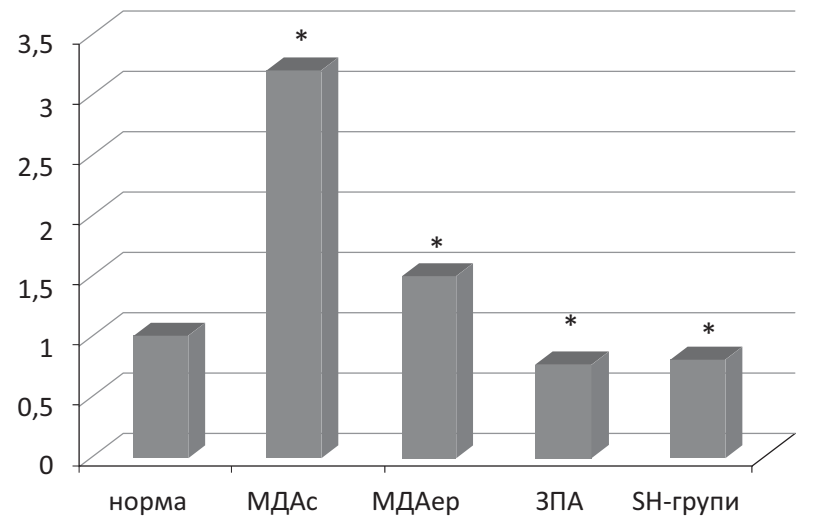

* - різниця з нормою достовірна $(\mathrm{p}<0,001)$

Рис. 2. Показники ПОЛ та АОС в крові хворих на XXH II-IV ст.

Серед обстежених 90 хворих на XXH II-IV ст. у 39 (43\%) реєструвались атеросклеротичні зміни сонних артерій. Серед них потовщення КIM (від 0,91 до 1,29 мм) визначили у 22 (56\%) хворих та наявність АТБ (КIM $\geq 1,3$ мм) у 17 (44\%) хворих. Двобічне атеросклеротичне ураження сонних артерій спостерігалось у 14 (36\%) хворих на XXН II-IV ст. Показник КIM у хворих на XXH II-IV ст. складав $0,93(0,78: 1,30)$ мм. КIM характеризувалась гіперехогеністю, гетерогенністю та звивистістю ходу загальних сонних артерій з обох сторін. Гемодинамічні порушення та стенози були відсутні в усіх хворих.

Вивчаючи рівень КIM у хворих на XXH II-IV ст. у віковому аспекті виявлено, що при збільшенні віку достовірно підвищується рівень КIM $(\mathrm{p}=0,03)$. При цьому рівень КІМ складав: у віці до 45-55 років - 0,90 $(0,80: 1,07)$ мм; від 55 до 65 років - 0,85 $(0,70: 1,20)$ мм та у віці від 65 років $-1,25(0,95: 1,65)$ мм. (рис. 3).

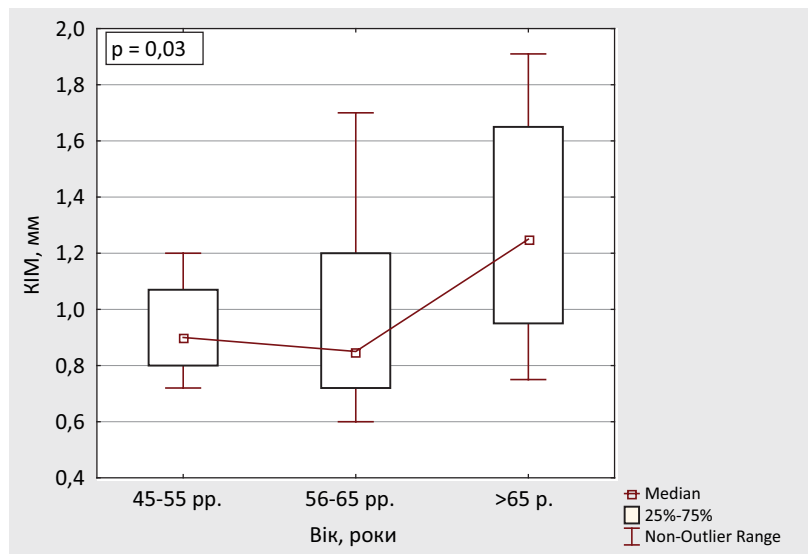

Рис. 3. Рівень КІМ залежно від віку хворих на XXH II-IV ст.
При вимірюванні регіонального АТ в артеріях нижніх кінцівок з оцінкою ГПІ у 49 (40,8\%) хворих на XXH II-IV ст. був зареєстрований початковий ступінь атеросклерозу периферичних артерій (ГПI від 0,9 до 0,7). Показник ГПІ хворих на XXН III-IV складав $0,92(0,88: 1,00)$ та статистично відрізнявся від показника ГПІ у хворих на ХХН II ст. - 1,02 $(1,00: 1,20)(\mathrm{p}=0,0007)$ та групи здорових осіб $-1,19$ $(1,08 ; 1,20)(\mathrm{p}<0,0001)$ (рис.4).

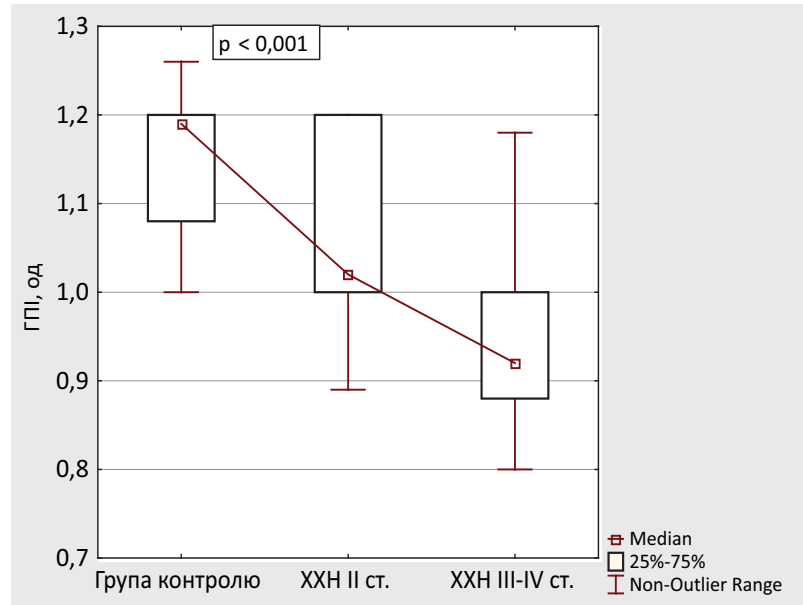

Рис. 4. Показник ГПІ у хворих на XXН II-IV ст. у порівнянні з контрольною групою.

Ендотеліальна дисфункція за показником ендотелійзалежної вазодилятації (ЕЗВД) спостерігалась у 71 (79\%) хворих на XXН II-IV ст. 3 числа хворих на XXH II-IV ст. із порушеною вазодилатаційною відповіддю у 12 (17\%) осіб відмічалась парадоксальна вазоконстрикція (ЕЗВД<0), у інших 12 $(17 \%)$ - була відсутня динаміка показників ЕЗВД під час проби з реактивною гіперемією (ЕЗВД=0) та у $47(66 \%)$ - неадекватна вазодилатація (ЕЗВД $<10 \%)$. Показник ЕЗВД $(8,1(5,2 ; 10,8) \%)$ у хворих на XXH III і IV ст. достовірно відрізнявся від хворих на XXН II ст. $(11,4(10,0: 14,3) \%)(p=0,03)$, а також від показника ЕЗВД здорових $(\mathrm{p}=0,002)$ (рис. 5).

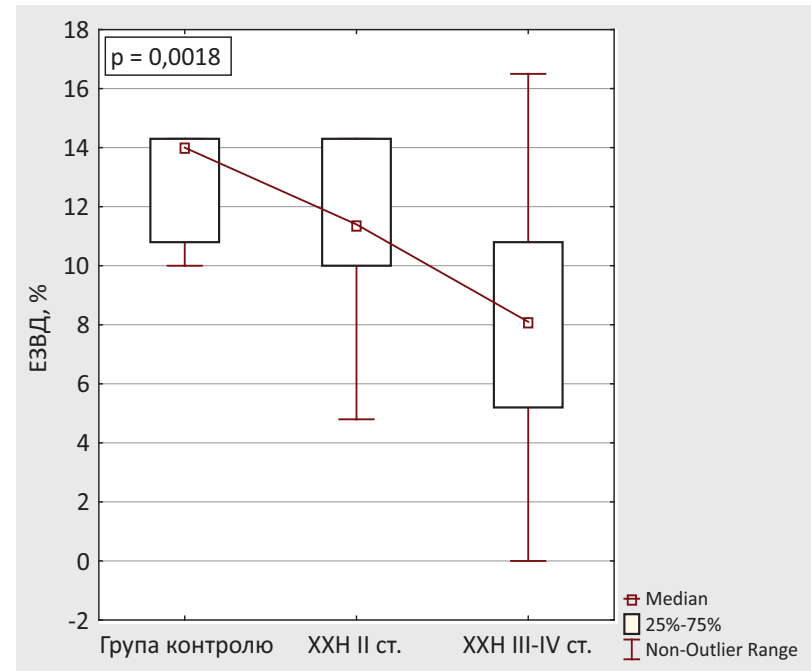

Рис. 5. Показник ЕЗВД у хворих на XXН II-IV ст. у порівнянні з контрольною групою. 
Нами був проведений кореляційний аналіз для виявлення можливого зв'язку між отриманими показниками атеросклеротичного ураження судин та ендотеліальної дисфункції та показниками ПОЛ/ АОС і про-та протизапальних цитокінів.

При цьому виявлений статистично значущий позитивний кореляційний зв'язок між рівнем МДА сироватки з одного боку, та показником КІМ з іншого $(\mathrm{r}=0,5, \mathrm{p}<0,001)$ (рис. 6$)$.

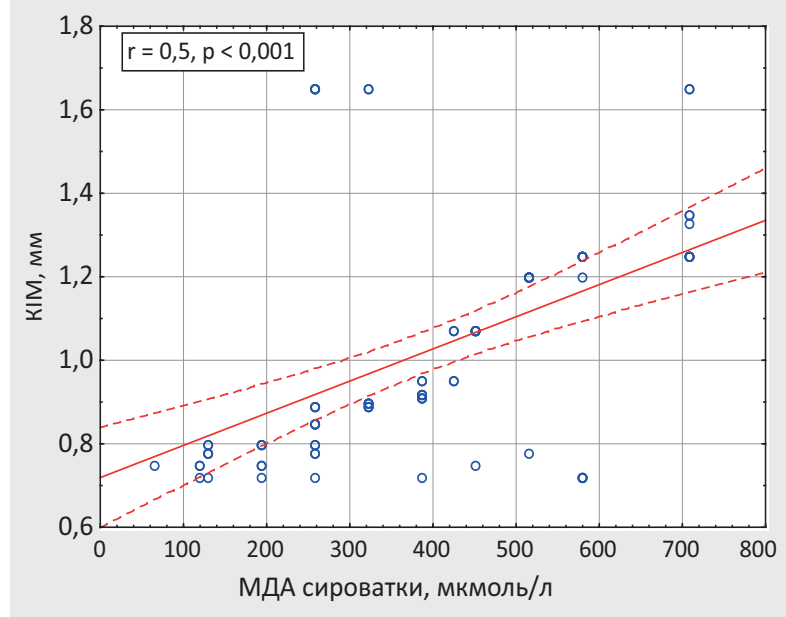

Рис. 6. Кореляційний зв'язок між рівнем МДА сироватки та показником КIM.

Також виявлений статистично значущий негативний кореляційний зв'язок між рівнем SH-груп 3 одного боку, та показником КIM, з іншого $(\mathrm{r}=$ $-0,56, \mathrm{p}<0,001)-$ рис. 7 .

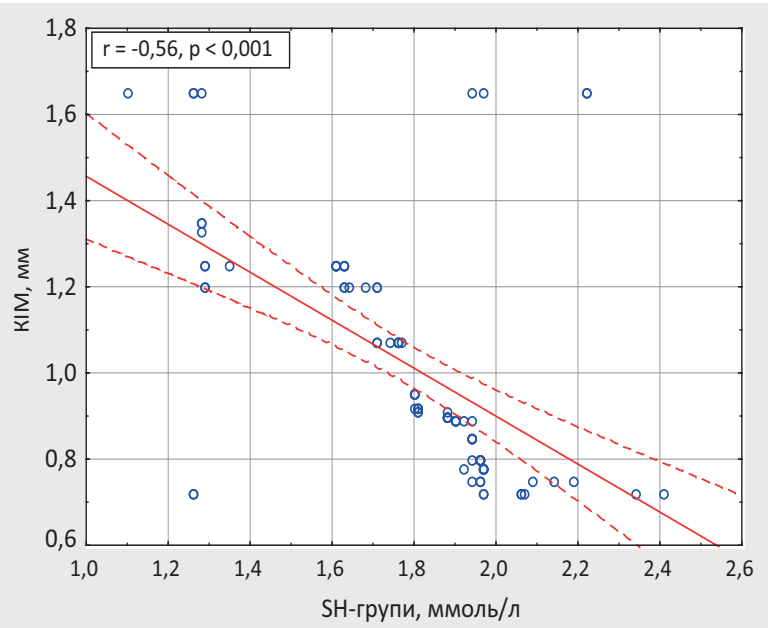

Рис. 7. Кореляційний зв’язок між рівнем SH-груп та показником КIM.

Виявлений статистично значущий позитивний кореляційний зв'язок між рівнем рівнем ІЛ-1 3 одного боку, та показником КIM з іншого ( $\mathrm{r}=0,57$, $\mathrm{p}<0,001)$ (рис. 8).

Також виявлений статистично значущий негативний кореляційний зв'язок між рівнем ІЛ$10 з$ одного боку, та показником КІМ, з іншого $(\mathrm{r}=-0,76, \mathrm{p}<0,001)-$ рис. 9 .

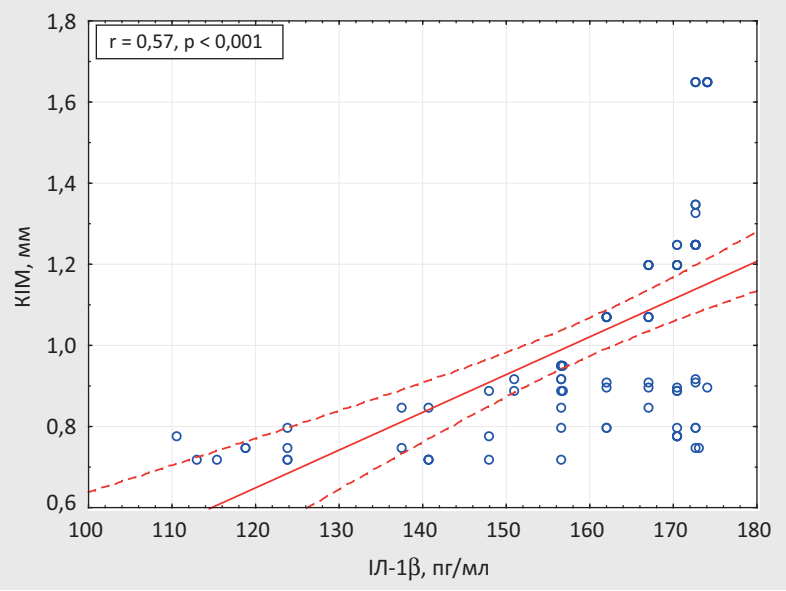

Рис. 8. Кореляційний зв’язок між рівнем ІЛ-1 $\beta$ та показником КIM.

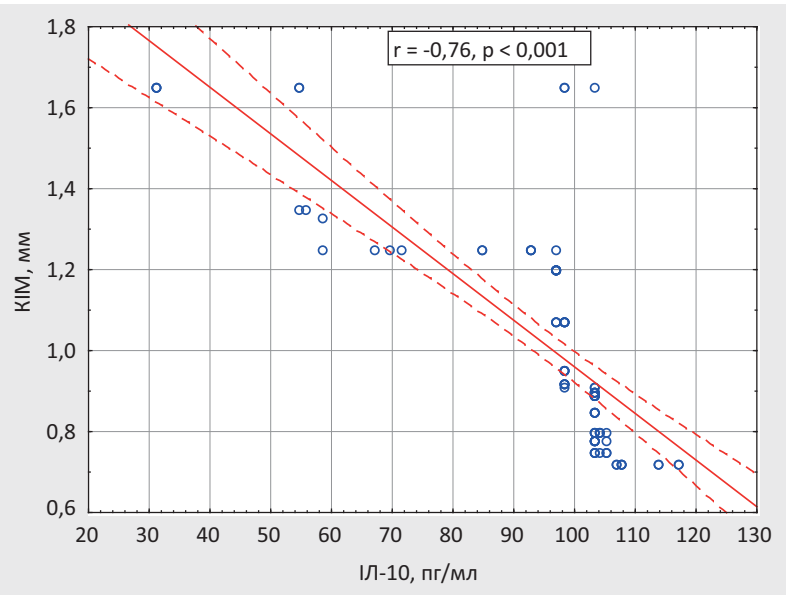

Рис. 9. Кореляційний зв'язок між рівнем ІЛ-10 та показником КIM.

Виявлений статистично значущий позитивний кореляційний зв'язок між рівнем ЗПА еритроцитів з одного боку, та показником ГПІ з іншого ( $\mathrm{r}=$ $0,34, \mathrm{p}=0,001)($ рис. 10$)$

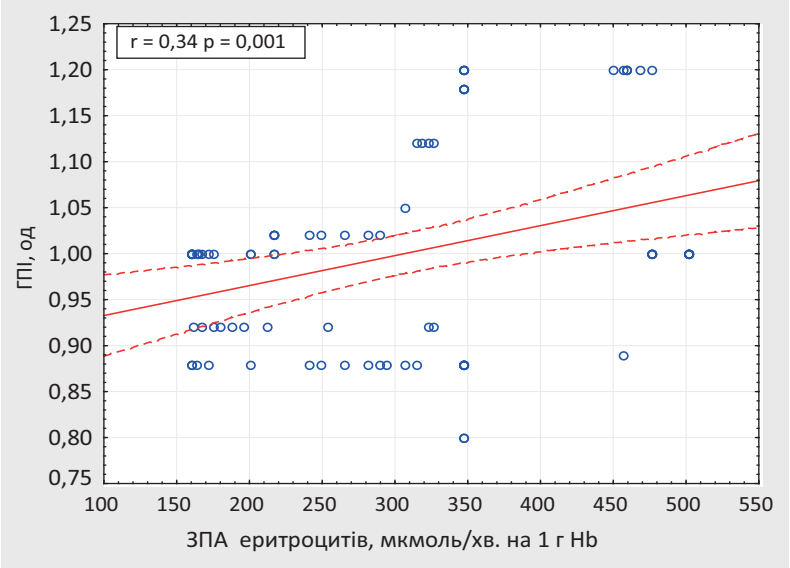

Рис. 10. Кореляційний зв'язок між рівнем ЗПА еритроцитів та показником ГПІ.

Також виявлений статистично значущий негативний кореляційний зв'язок між рівнем МДА еритроцитів з одного боку, та показником ГПІ, 3 іншого $(\mathrm{r}=-0,8, \mathrm{p}<0,001)$ (рис. 11$)$. 


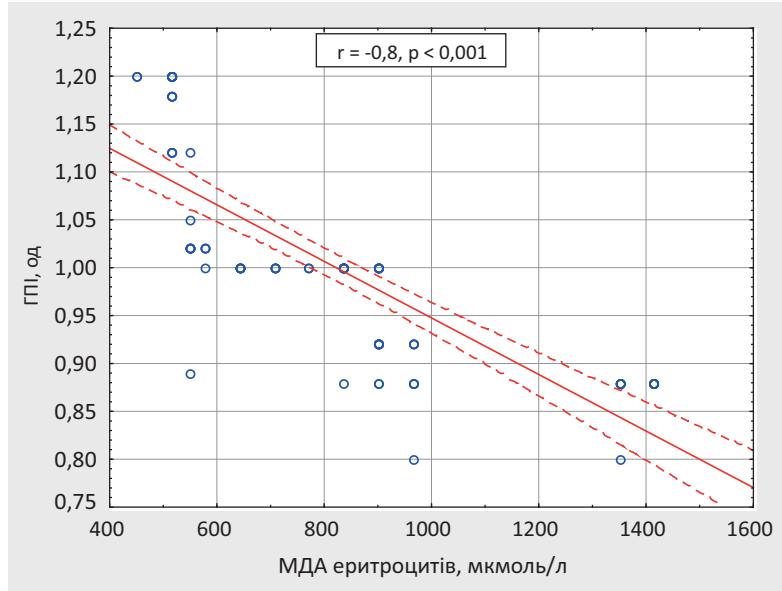

Рис. 11. Кореляційний зв'язок між рівнем МДА еритроцитів та показником ГПІ.

Також виявлений статистично значущий негативний кореляційний зв'язок між рівнем ІЛ-1 $\beta$, пг/мл з одного боку, та показником ГПІ, з іншого $(\mathrm{r}=-0,7, \mathrm{p}<0,001)$ (рис. 12).

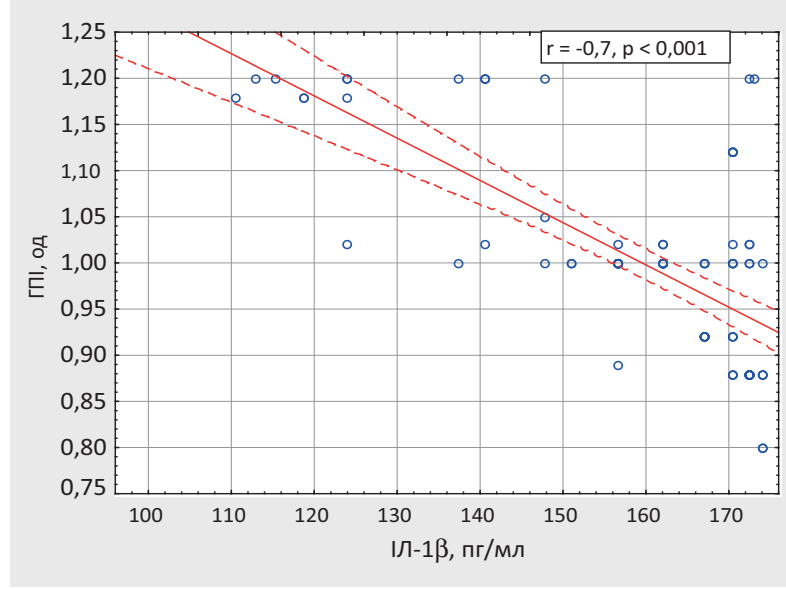

Рис. 12. Кореляційний зв'язок між рівнем ІЛ- $1 \beta$ еритроцитів та показником ГПІ.

Виявлений статистично значущий позитивний кореляційний зв'язок між рівнем ЗПА еритроцитів 3 одного боку, та показником ЕЗВД з іншого ( $\mathrm{r}=$ $0,25, \mathrm{p}=0,016)$ (рис. 13).

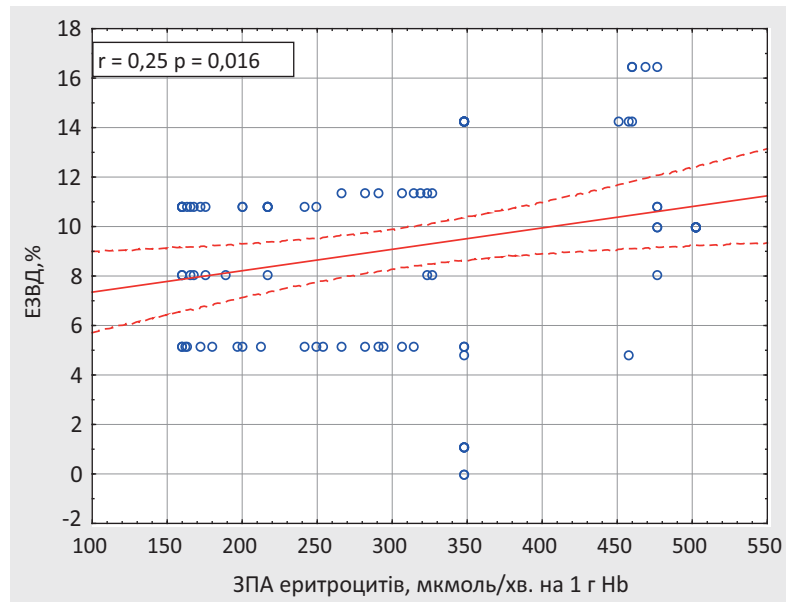

Рис. 13. Кореляційний зв'язок між рівнем ЗПА еритроцитів та показником ЕЗВД.
Також виявлений статистично значущий негативний кореляційний зв'язок між рівнем МДА сироватки з одного боку, та показником ЕЗВД, 3 іншого $(\mathrm{r}=-0,42, \mathrm{p}<0,001)$ (рис. 14).

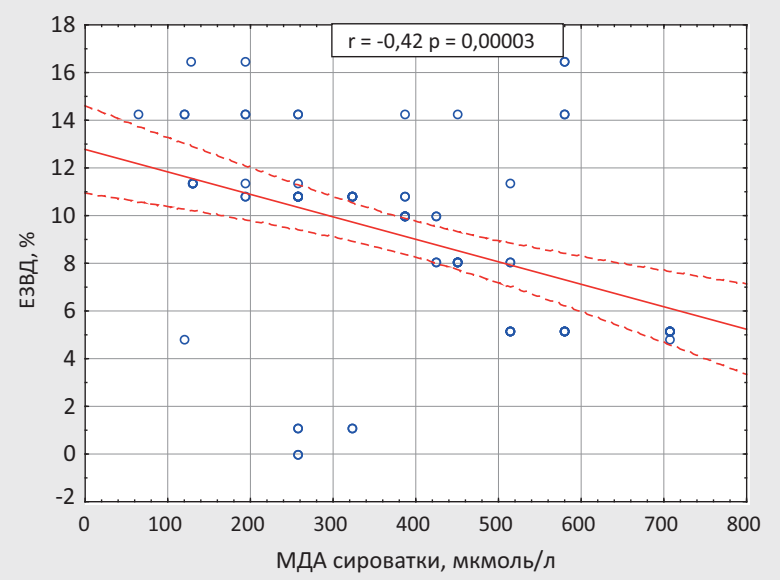

Рис. 14. Кореляційний зв'язок між рівнем МДА сироватки та показником ЕЗВД.

Також виявлений статистично значущий негативний кореляційний зв'язок між рівнем ІЛ-1 з одного боку, та показником ЕЗВД, з іншого ( $\mathrm{r}=$ $-0,67, \mathrm{p}<0,001)$ (рис. 15).

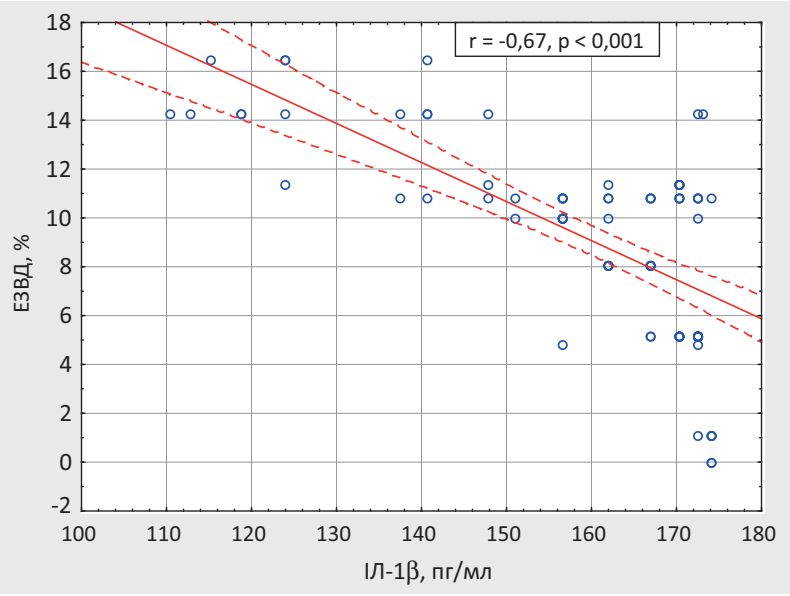

Рис. 15. Кореляційний зв'язок між рівнем ІЛ-1 сироватки та показником ЕЗВД.

ВИСНОВКИ. Патологічні процеси активації ПОЛ та виснаження АОС, хронічного запалення тісно пов'язані між собою та причетні до прогресування атеросклеротичного ураження судин.

1. Наявність атеросклеротичних процесів констатовано у більшості пацієнтів з ХХН: потовщення КІМ у 56,41\% хворих та наявність АТБ у 43,59\% хворих. Двобічне атеросклеротичне ураження сонних артерій спостерігалось у 35,90\% хворих на XXH II-IV ст. Атеросклеротичні процеси констатовані як у сонних артерій, так і в артеріях нижніх кінцівок (за оцінкою ГПІ).

2. Встановлено, що атеросклеротичні процеси (КIM) помірно позитивно корелювали з рівнем показників ПОЛ (МДА плазми), зворотньо - 3 
показниками AOC (рівнем SH-груп). ГПI, навпаки, зворотно корелював з показниками ПОЛ та помірно позитивно із показниками АOC.

3. Встановлено, що атеросклеротичні процеси (KIM) помірно позитивно корелювали з рівнем прозапальних цитокінів та зворотно - 3 показниками протизапальних). ГПІ, навпаки, зворотно корелював з показниками ПОЛ та помірно позитивно із показниками АОС.

4. Ендотеліальна дисфункція (за показниками ЕЗВД) встановлена у 79\% хворих на XXН II-IV ст.: у 16,9\% осіб констатована парадоксальна вазоконстрикція (ЕЗВД<0), у 16,9\% - була відсутня динаміка показників ЕЗВД під час проби 3 реактивною гіперемією та у 66,2\% - неадекватна вазодилатація. Ендотеліальна дисфункція у хворих на XXН III і IV ст. $(8,1[5,2 ; 10,8] \%)$ достовірно відрізнявся від хворих на ХXН II ст. $(11,4[10,0 ; 14,3] \%)(p=0,03)$, а також від показника ЕЗВД здорових $(\mathrm{p}=0,002)$.

5. Показники ЕЗВД зворотно корелювали з показниками ПОЛ та прозапальними цитокінами, та позитивно з показниками АОС та протизапальними цитокінами. Отримані дані свідчать, що розвиток ендотеліальної дисфункції тісно пов'язаний з активацією ПОЛ та хронічним запаленням.

\section{ЛIТЕРАТУРА:}

1. Бабак О. Я. Морфологічні зміни судинної стінки сонних артерій у хворих на хронічний гломерулонефрит / О. Я. Бабак, Г. В. Лісова // Медицина сьогодні і завтра. - 2011. - № 4 (53). - С. 45-48.

2. Класифікація хвороб сечової системи для нефрологічної практики : матеріали II з'їзду нефрологів України, (Харків, 24 вересня 2005 р.) / Український журнал нефрології та діалізу. - 2005. - № 4 (7). C. 2-14.

3. Національний реєстр хворих на хронічну хворобу нирок : 2013 рік / уклад. . Н. І. Козлюк, С. С. Ніколаєнко, М. В. Кулизький; Державна установа „Інститут нефрології НАМН України”; гол. ред. М. О. Колесник. - К., 2014. - 89 с.

4. Прогресування хронічної хвороби нирок: роль оксидативного стресу та хронічного запалення / I.O. Дудар, О. М. Лобода, І.В. Красюк, В.В. Алєксєєва, В.Є. Дріянська, Л. В. Король // Науковий вісник Національного медичного університету імені О.О. Богомольця. - 2013. - №3 (42). - С. 171-176.

5. Прогресування хронічної хвороби нирок : стан оксидативного стресу на різних стадіях XXН / I. О. Дудар, О. М. Лобода, Л. В. Король, В. В. Алексєєва // Український журнал нефрології та діалізу. - 2012. № 2 (34). - C. 18-23.
6. Association of carotid artery intima-media thickness, plaques, and C-reactive protein with future cardiovascular disease and all-cause mortality: the Cardiovascular Health Study / J. J. Cao, A. M. Arnold, T. A. Manolio [et al.] // Circulation. - 2007. - Vol. 116. - P. 32-38.

7. Ballantyne common carotid artery intima-media thickness is as good as carotid intima-media hickness of all carotid artery segments in improving prediction of coronary heart disease risk in the Atherosclerosis Risk in Communities (ARIC) study / V. Nambi, L. Chambless, M. He [et al.] // Eur. Heart J. - 2011. - V. 33 (2). P. 183-190.

8. Carotid ultrasound identifies high risk subclinical atherosclerosis in adults with low framing ham risk scores / $\mathrm{M}$. F. Eleid, S. J. Lester, T. L. Wiedenbeck [et al.] // J. of the American Society of Echocardiography. - 2010. V. 23, № 8. - P. 802-808.

9. Chronic kidney disease and the risks of death, cardiovascular events, and hospitalization / A.S. Go, G.M. Chertow, D. Fan [et al.] // N. Engl. J. Med. - 2004. Vol. 351. - P. 1296-1305.

10. Creagh E. M. Caspase-activation pathways in apoptosis and immunity / E. M. Creagh, H. Conroy, J. Martin Seamus // Immunological Reviews. - 2003. - Vol. 193 (1). - P. 10

11. Hajjar K. A. New concepts in fibrinolisis and angiogenesis / K. A. Hajjar, A. Deora // Curr. Atheroscler. Rep. - 2000. - Vol. 2. - P. 417-421.

12. Improvements in risk stratification for the occurrence of cardiovascular disease by imaging subclinical atherosclerosis: a systematic review / S. A. E. Peters, H. M. den Ruijter, M. L. Bots, K. G. M. Moons // Heart. - 2011. - № 98 (3). - P. 177-184.

13. Intimal plus medial thickness of the arterial wall: a direct measurement with ultrasound imaging / P. Pignoli, E. Tremoli, A. Poli [et al.] // Circulation. - 1986. V. 74. - P. 1399-1406.

14. Is carotid intima media thickness useful for individual prediction of cardiovascular risk? Ten-year results from the Carotid Atherosclerosis Progression Study (CAPS) / M. W. Lorenz, C. Schaefer, H. Steinmetz [et al.] // Eur. Heart J. - 2010. - Vol. 31. - P. 2041-2048.

15. Landray M. J. Inflammation, endothelial dysfunction and platelet activation in patients with chronic kidney disease: the chronic renal impairment in Birmingham (CRIB) Study / M. J. Landray, D. C. Wheeler // Am. J. Kidney Dis. - 2004. - № 43 (2). - P. 244-253.

16. Prediction of clinical cardiovascular events with carotid intimamedia thickness: a systematic review and metaanalysis / M. W. Lorenz, H. S. Markus, M. L. Bots [et al.] // Circulation. - 2007. - Vol. 115. - P. 459-467.

17. Vascular age: integrating carotid intima-media thickness measurements with global coronary risk assessment / J. H. Stein, M. C. Fraizer, S. E. Aeschlimann [et al.] // Clin Cardiol. - 2004. - Vol. 27. - P. 388-392.

Надійшла до редакції 11.01.2015 Прийнята до друку 26.01.2015 